\title{
Reflection and activism: Aracy Lopes da Silva and the National Education Plan
}

\section{Luís Donisete Benzi Grupioni \\ Institute for Research and Indigenous Formation}

It is difficult to think of another topic that simultaneously poses as many challenges to anthropological reflection and indigenist activism as the question of schooling among indigenous peoples. By taking both sets of challenges in her stride, anthropologist Aracy Lopes da Silva became a leading light in the field of indigenous education, her commitment to the issue spanning from the 197os when she headed the Education Subcommittee of the São Paulo Pro-Indian Commission, to the 2000 s when she completed a series of edited works that disseminated the results of a wide-ranging research project on Anthropology, History and Education, coordinated by herself at the University of São Paulo. Across these thirty years, we see an anthropologist deeply committed to the rigour of the discipline, embraced with enthusiasm, and to a cause for which she fought vigorously. She was widely recognized both inside and outside academia. While reflection and activism often overlap and merge, one almost always compromising the other, Aracy Lopes da Silva's academic production and activities in the area of indigenous education reveal that she knew, like few others, how to administrate them, weaving connections and interfaces where appropriate, preserving open spaces when necessary.

As well as her studies of the Xavante and her work on their onomastics, mythology, cosmology and indigenous history, Aracy Lopes da Silva set various benchmarks in the field of anthropology and education. Two collections edited by her helped shape the studies of schools and indigenous peoples in Brazil. The first, The Question of Indigenous Education (A questão da educação indígena), published in 1979, collates papers and reflections from the First National Meeting of Work on Indigenous Education. Promoted as part of the activities of the Education Subcommittee of the São Paulo Pro-Indian Commission, the meeting brought together more than fifty educators, indigenists, missionaries, linguists, anthropologists, sociologists, physicians and legal experts in order to swap information and experiences relating to formal education in indigenous lands. The second, The Indigenous Question: guidelines 
for primary school teachers (A questão indígena na sala de aula: subsídios para professores de 1‥ e 2․ Graus), from 1987, brings together articles by specialists with critiques and proposals for a more adequate approach to the indigenous theme in schools. This latter volume led to a sequel some years later, a new collection of essays entitled Indigenous Themes in the School: new guidelines for primary school teachers (A temática indígena na escola: novos subsídios para professores de 1‥ e 2․graus, published by MEC, UNESCO and Mari/USP in 1995. She also authored a guidebook for educators, Índios (from 1988) and a book for children and adolescents, Histories of Truth (Histórias de Verdade) (from 1984). These works had a profound impact on the academic debate over schooling among indigenous peoples, on the dissemination of anthropological knowledge to a public wider than the specialists, and on the public policies gradually being adapted at the time to the new legal frameworks instituted by the 1988 Brazilian Constitution still in force today.

Another set of books, published more recently, consolidated and disseminated an interdisciplinary and inter-institutional approach, the main objective of which was to develop an approach to education that promoted sociocultural diversity, combining the perspectives of anthropology and history on education and taking as an empirical and theoretical reference point the intercultural dialogue between Brazil's indigenous and nonindigenous populations. This collective enterprise highlighted the school as a key space for cultivating new forms of coexistence and reflection in this field. Under Aracy's coordination, 19 research subprojects set about investigating topics like socialization and knowledge transmission processes in indigenous societies; the impact of the introduction of writing and schooling; and the historical relations between the State and indigenous societies in the field of education. This collective work resulted in what are today fundamental collections in this field of studies: Anthropology, History and Education: the indigenous question and schools (Antropologia, História e Educação: a questão indígena e a escolar) (2001); Teaching Practices in Indigenous Schools (Práticas pedagógicas na escola indígena) (2001) and Indian Children: anthropological essays (Crianças Indígenas: ensaios antropológicos) (2002).

Between the first and second set of publications, the more visible dimension of many histories and processes, we find Aracy giving lectures at university, training students, supervising dissertations and theses on topics like schools, children, infancy, socialization and knowledge transmission, 
publishing diverse articles, and working politically in both government and non-government spheres in search of a better direction for school education in the villages.

Under her leadership, the Mari Indigenous Education Group was set up at the Department of Anthropology of the University of São Paulo - a space designed to articulate anthropological reflections on the potential for new school education practices in indigenous lands. Based on the valorization of indigenous languages, knowledge and practices on one hand, and on political engagement and activism on the other, the group set out to promote rights and public policies capable of transforming the meaning of the school as an institution within indigenous communities.

At the invitation of Silvio Coelho dos Santos, in his capacity as president of the Brazilian Anthropology Association, Aracy represented the association on the National Committee for Indigenous School Education following its creation at the Ministry of Education (MEC) after the latter was assigned the mission of coordinating indigenous school education in the country in 1991. There she contributed to the elaboration of the National Guidelines for Indigenous Education (Diretrizes Nacionais de Educação Escolar Indígena) (1993) and the National Curricular Reference for Indigenous Schools (Referencial Curricular Nacional para as Escolas Indígenas) (1998), two foundational documents underlying the paradigm shift experienced by indigenous school education in recent years: from State welfare actions to an indigenous right. This work alongside the State, seeking to inscribe anthropological and indigenist concerns in the public policies targeted at Indians, in which the latter acquired visibility in diverse settings, was always undertaken by Aracy in a playful, critical and non-partisan way, anchored in her endeavour to theorize the question of schooling among indigenous peoples without ever shrinking from pointing out the lapses and deficiencies of government action.

\section{Indigenous school education in the law bills tof the National Education Plan}

Engaged along with other anthropologists, linguists, educators and indigenists in constructing public policies that incorporated respect for sociocultural diversity, Aracy Lopes da Silva played an important role, albeit 
little known, in defining proposals that inserted the issue of school education in the 2001 National Education Plan (NEP) Law.

Following approval of the Law of Directives and Bases of National Education in 1996, the Federal Government was obliged to present a law bill to the National Congress within the space of a year containing a National Education Plan, with directives and goals for the next ten years, in line with the World Declaration on Education for All, adopted at the Jomtien Conference (Thailand) in 1990.

Responsibility for drafting a proposal to be presented by the Executive fell to the Ministry of Education. This in turn assigned one of its agencies, the National Institute of Educational Studies and Research (INEP), with the task of drafting and presenting a law bill containing the plan - a task that was carried out with the assistance of the Higher Education Studies Nucleus (NUPES) of the University of São Paulo. Faced with this mission, the anthropologist Eunice Ribeiro Durham invited Aracy Lopes da Silva and myself to write a preliminary version of a chapter that would contain a set of global and specific goals capable of guiding the actions of the Brazilian state for indigenous school education over the next decade. As part of the activities of Mari/USP, we worked on a text that included a history and diagnosis of indigenous education, proposing targets to be implemented over the short and long term. This draft text was discussed by INEP and MEC's National Committee of Indigenous School Education, which united representatives of government bodies and civil society organizations. Following various additions and modifications, this text was included in the proposal submitted by the Federal Government to the National Congress in February 1998.

This proposal by the Executive was presented to the National Congress some days after the submission of another law bill entitled the National Education Plan - A Proposal of Brazilian Society. This latter proposal had resulted from a wide-ranging discussion process among educational movements consolidated in 1996 and 1997 by the National Forum in Defence of Public Schooling at the $1^{\text {st }}$ and $2^{\text {nd }}$ National Education Congress, held in Belo Horizonte (MG). The federal deputy Ivan Valente, then still a member of the Workers' Party (PT) representing São Paulo, and the member of a cross-party parliamentary lobby in defence of education, backed the proposal and submitted it as a law bill. 
To the surprise of those who had not been accompanying this movement, the Civil Society NEP, as it became known, contained just a vague reference to the fact that Brazil's indigenous population had the right to quality school education that simultaneously respected their cultures and social organization, and included them socially and politically in national life. Encouraged by a group of students from USP's Postgraduate Course in Anthropology, Aracy Lopes da Silva drafted an amendment to the Civil Society NEP, which was presented by herself to Deputy Ivan Valente, with the aim of filling the gap in the plan: were the latter to be approved in its proposed form, it would have effectively omitted a series of important proposals for consolidating the indigenous right to differentiated education and for structuring this new educational modality within the teaching systems. However, the initiative

- which revealed Aracy's personal commitment to improving the legal framework supporting the right of Brazil's indigenous peoples to a differentiated education - was not backed and the proposals formulated in this text drafted by Aracy were omitted. The Civil Society NEP bill continued to be discussed in the National Congress ignoring the demand to regulate this new teaching modality that was gradually extending its reach within the country's indigenous policies.

The National Congress appointed Deputy Nelson Marchezan (PSDB-RS) to coordinate drafting the new law. He produced a Clean Bill, based on the plan presented by the government, but inverting the order of priority of the plans presented in the Legislature. Making use of the diagnosis of the educational situation outlined in the Civil Society NEP, but prioritizing the directives, objectives and goals of the government's own NEP, Marchezan drafted a new bill for the National Education Plan that, after debates, hearings and the inclusion of amendments and modifications, was approved as Law 10.172 by the National Congress in January 2001. Indigenous school education was included in a specific chapter, as had been proposed in the law bill presented by the Executive, containing a diagnosis, directives and 21 objectives and goals.

\section{On Aracy's text}

The text published by Vibrant in this issue, in homage to this anthropologist who, like few others, allied anthropological reflection 
with indigenist activism in favour of the rights of indigenous peoples, remained unpublished, circulating among a small number of people only. It comprises the amendment drafted by Aracy to the proposal for the Civil Society NEP. As narrated above, this was eventually omitted. A text certainly dated and written for a specific purpose comprises an important historical document, revealing the kinds of ideas, practices and movements that become submerged when laws and regulations are approved and issued. The text also reveals Aracy's personal efforts and engagement towards incorporating proposals into a law bill with the aim of reorienting the persistently oppressive form assumed by the school institution in indigenous contexts.

Describing a series of innovative experiences in school education then under way in different villages around the country, Aracy emphasizes the possibility of moving beyond the integrationism and assimilationism that had marked the processes of introducing writing and schooling among indigenous groups since the beginnings of colonization. In the text she proposes guidelines that could consolidate these experiences as models for structuring the State's action in the provision of a school education respectful of the linguistic and cultural singularities of indigenous peoples and assuring them better forms of inclusion in Brazilian society. Proposing an administrative model for structuring and orienting this new modality within the existing teaching systems, her text reveals a concern to ensure that the scientific, aesthetic and philosophical knowledge of indigenous peoples would not succumb to the imposition of school knowledge.

Various of Aracy's proposals in this text, which combines ideas and proposals under discussion at that time, were incorporated over the years in government initiatives and programs, some of the well-executed, others completely distorted. More than fifteen years after it was written, this text has a documental importance as a snapshot of the ideas and reflections found at the end of the 1990 os on indigenous school education. Today it also acquires a very pertinent and critical posture in the face of the current distortions of government policy for indigenous school education. Some of her proposals in the area remain avant-garde, still found on the list of demands made by the indigenous movement. Reading it is not just a chance to revisit our recent past: it is an invitation to reflect on 
the present, not only on the issue of education in indigenous villages, but above all on the persistently difficult fate of indigenous peoples in Brazil.

Translated by David Rogers

\author{
Luís Donisete Benzi Grupioni \\ Institute for Research and Indigenous Training \\ luisdonisete@institutoiepe.org.br
}

